\title{
Orexin Signaling in the VTA Gates Morphine-Induced Synaptic Plasticity
}

\author{
Corey Baimel ${ }^{1,2}$ and Stephanie L. Borgland ${ }^{2}$ \\ ${ }^{1}$ Department of Anesthesiology, Pharmacology and Therapeutics, University of British Columbia, Vancouver, British Columbia V6T 1Z3, Canada, and \\ ${ }^{2}$ Hotchkiss Brain Institute, University of Calgary, Calgary, Alberta T2N 4N1, Canada
}

\begin{abstract}
Dopamine neurons in the ventral tegmental area (VTA) are a key target of addictive drugs, and neuroplasticity in this region may underlie some of the core features of addiction. From the very first exposure, all drugs of abuse induce synaptic plasticity in the VTA. However, it is not well understood how this diverse group of drugs brings about common synaptic change. Orexin (also known as hypocretin) is a lateral hypothalamic neuropeptide released into the VTA that promotes drug-seeking behaviors and potentiates excitatory synaptic transmission onto VTA dopamine neurons. Here we show that signaling at orexin receptor type 1 (OxR1) in the VTA is required for morphine-induced plasticity of dopamine neurons. Systemic or intra-VTA administration of the 0xR1 antagonist SB 334867 in rats blocked a morphine-induced increase in the AMPAR/NMDAR ratio, an increase in presynaptic glutamate release, and a postsynaptic change in AMPAR number or function, including a switch in subunit composition. Furthermore, SB 334867 blocked a morphine-induced decrease in presynaptic GABA release, and a morphine-induced shift in the balance of excitatory and inhibitory synaptic inputs to dopamine neurons. These findings identify a novel role for orexin in morphine-induced plasticity in the VTA and provide a mechanism by which orexin can gate the output of dopamine neurons.
\end{abstract}

Key words: AMPA; dopamine; morphine; NMDA; orexin; ventral tegmental area

\section{Introduction}

The mesolimbic dopamine system is a well recognized target of addictive drugs, and plasticity within this neural circuitry is involved in the development and maintenance of addiction (Hyman et al., 2006; Kauer and Malenka, 2007). The activity and output of ventral tegmental area (VTA) dopamine neurons are tightly regulated by excitatory glutamate and inhibitory GABA synaptic inputs, and drug-induced plasticity at these synapses occurs with the very first drug exposure. A single in vivo injection of multiple addictive drugs induces a long-term potentiation (LTP) of excitatory synaptic transmission in the VTA (Ungless et al., 2001; Saal et al., 2003; Brown et al., 2010). This drug-evoked plasticity is thought to increase the incentive properties of the drug, to mediate early behavioral responses to drug exposure, and to trigger long-term neural adaptations in regions that receive dopamine input (Kauer and Malenka, 2007). Moreover, drug treatment inhibits inhibitory control mechanisms that increase GABA transmission to the VTA [GABAergic LTP $\left(\mathrm{LTP}_{\mathrm{GABA}}\right)$; Nu-

\footnotetext{
Received Oct. 22, 2014; revised March 8, 2015; accepted April 7, 2015.

Author contributions: C.B. and S.L.B. designed research; C.B. performed research; C.B. and S.L.B. analyzed data; C.B. and S.L.B. wrote the paper.

This research was supported by National Sciences and Engineering Research Council (Canada) Discovery Grant DG 372517 and Canadian Institutes of Health Research New Investigator Award MOP104357 to S.L.B., C.B. was supported by a Brain Canada graduate studentship.

The authors declare no competing financial interests.

Correspondence should be addressed to Stephanie L. Borgland, Hotchkiss Brain Institute, University of Calgary, 3330 Hospital Drive NW, Calgary, AB T2N 4N1, Canada. E-mail: s.borgland@ucalgary.ca.

DOI:10.1523/JNEUROSCI.4385-14.2015

Copyright $\odot 2015$ the authors $\quad 0270-6474 / 15 / 357295-09 \$ 15.00 / 0$
}

gent et al., 2007; Niehaus et al., 2010; Graziane et al., 2013], likely further increasing the incentive properties of the drug.

Orexin neurons have emerged as an important mediator of drug-seeking behavior and alter synaptic transmission in the VTA. Orexins are neuropeptides synthesized in the lateral hypothalamus ( $\mathrm{LH}$ ) that contribute to arousal, feeding, and reward seeking (Sakurai et al., 1998; de Lecea et al., 1998; Harris et al., 2005; Adamantidis et al., 2007). Orexin A and B signal at two G-protein-coupled receptors, OxR1 and OxR2, which are widely expressed in the brain, including in the VTA (Korotkova et al., 2003; Narita et al., 2006). Orexin neurons are activated by drug cues (Harris et al., 2005), and drug administration enhances excitatory drive at glutamate synapses onto orexin neurons (Yeoh et al., 2012; Rao et al., 2013). Importantly, orexins mediate drug seeking through their projections to the VTA (Harris et al., 2005; Borgland et al., 2006; Narita et al., 2006). Orexins increase the firing rate of dopamine neurons and can enhance dopamine release in downstream target structures (Korotkova et al., 2003; Narita et al., 2006, 2007; Vittoz and Berridge, 2006; Vittoz et al., 2008; España et al., 2010). Short-term administration of orexin A increases NMDA receptor (NMDAR) current amplitudes in dopamine neurons (Borgland et al., 2006), an effect that is enhanced by long-term drug self-administration (Borgland et al., 2009), and promotes a long-term increase in AMPAR receptor (AMPAR) signaling (Borgland et al., 2006).

Drugs of abuse differ greatly in terms of their behavioral profiles and molecular targets. Although the mechanisms by which addictive drugs increase phasic dopamine release have been well characterized (Lüscher and Ungless, 2006), it is unclear how these drugs all converge to induce synaptic plasticity in the VTA. Pre- 
viously, we found that systemic administration of an OxR1 antagonist blocks both cocaine-induced synaptic plasticity at excitatory synapses in the VTA and the development of behavioral sensitization (Borgland et al., 2006). However, it is unknown whether orexin contributes to plasticity in the VTA induced by other drugs with different mechanisms of action. Here, we used wholecell patch-clamp electrophysiology to elucidate the contribution of orexin signaling to morphine-induced synaptic plasticity of VTA dopamine neurons.

\section{Materials and Methods}

Animals. All protocols were performed in accordance with the ethical guidelines established by the Canadian Council for Animal Care, and were approved by the University of British Columbia and the University of Calgary Animal Care Committees. Sprague Dawley rats were obtained from the University of British Columbia breeding facility or Charles River Laboratories and were housed in groups of two to six, except following surgery, at which time rats were single housed. Rats were maintained on a $12 \mathrm{~h}$ light/dark schedule, and were given food and water ad libitum. All experiments were performed during the animals' light cycle.

Electrophysiology. All electrophysiological recordings were performed in slice preparations from male Sprague Dawley rats [postnatal day 19 (P19) to P30]. Briefly, rats were anesthetized with isoflurane and decapitated, and their brains were extracted into ice-cold sucrose solution containing the following (in $\mathrm{mm}$ ): 75 sucrose, $87 \mathrm{NaCl}, 2.5 \mathrm{KCl}, 1.25$ $\mathrm{NaH}_{2} \mathrm{PO}_{4}, 25 \mathrm{NaHCO}_{3}, 7 \mathrm{MgCl}_{2}$, and $0.95 \mathrm{CaCl}_{2}$. Horizontal sections $(250 \mu \mathrm{m})$ containing the VTA were cut on a vibratome (Leica), and incubated in a holding chamber for at least $45 \mathrm{~min}$ before being transferred to a recording chamber and superfused with bicarbonate-buffered solution (artificial CSF) containing the following (in $\mathrm{mM}$ ): $126 \mathrm{NaCl}, 1.6$ $\mathrm{KCl}, 1.1 \mathrm{NaH}_{2} \mathrm{PO}_{4}, 1.4 \mathrm{MgCl}_{2}, 2.4 \mathrm{CaCl}_{2}, 26 \mathrm{NaHCO}_{3}$, and 11 glucose $(32 \mathrm{C}-34 \mathrm{C})$, and saturated with $95 \% \mathrm{O}_{2} / 5 \% \mathrm{CO}_{2}$. Cells were visualized using infrared differential contrast video microscopy, and whole-cell voltage-clamp recordings were made using a MultiClamp 700B Amplifier (Molecular Devices). Recording electrodes (3-5 M 2 ) were filled with the following (in $\mathrm{mM}$ ): 117 cesium methanesulfonate, 20 HEPES, 0.4 EGTA, 2.8 NaCl, 5 TEA-Cl, 2.5 Mg-ATP, and 0.25 Na-GTP, pH 7.2-7.3 and 270-285 mOsm to record EPSCs; and $0.1 \mathrm{~mm}$ spermine was added only when examining the rectification index. For IPSCs, electrodes were filled with the following (in mM): $125 \mathrm{KCl}, 2.8 \mathrm{NaCl}, 2 \mathrm{MgCl}_{2}, 10 \mathrm{HEPES}$, 0.6 EGTA, 2.5 Mg-ATP, and 0.25 Na-GTP, pH 7.2-7.3 and 270-285 mOsm. Series resistance $(10-25 \mathrm{M} \Omega$ ) and input resistance were monitored on-line with a $10 \mathrm{mV}$ depolarizing step ( $400 \mathrm{~ms}$ ) given before every afferent stimulus. Dopamine neurons, which are the most abundant cell type in the VTA, were located medial to the medial nucleus of the optic tract and were identified by the presence of a large hyperpolarizing cation current, and in a subset of cells by tyrosine hydroxylase staining according to previously published methods (Thompson and Borgland, 2013). A bipolar stimulating electrode was placed $100-300 \mu \mathrm{m}$ rostral to the recording electrode and was used to stimulate either excitatory or inhibitory afferents at $0.1 \mathrm{~Hz}$. Neurons were voltage clamped at $-70 \mathrm{mV}$ to record AMPAR EPSCs. EPSCs were recorded in the presence of picrotoxin $(100 \mu \mathrm{M})$ to block $\mathrm{GABA}_{\mathrm{A}}$ receptor IPSCs; and IPSCs were recorded with strychnine $(1 \mu \mathrm{M})$ to block potential glycine IPSCs (Zheng and Johnson, 2001); with AP5 $(50 \mu \mathrm{M})$ and DNQX $(10 \mu \mathrm{M})$ to block excitatory synaptic transmission; and with sulpiride (200 nM) to block dopamine $\mathrm{D}_{2}$ receptor IPSCs (Gantz et al., 2013) in the bath solution.

The AMPAR/NMDAR ratio was recorded at $+40 \mathrm{mV}$ and was calculated according to previously published methods (Borgland et al., 2006). For the rectification index, AMPAR EPSCs were evoked at $-70,0$, and $+40 \mathrm{mV}$ in the presence of AP5 $(50 \mu \mathrm{M})$ and the polyamine spermine (via pipette, $0.1 \mathrm{~mm}$ ). The rectification index was calculated by dividing the gradient of the slope at negative potentials by the gradient of the slope at positive potentials.

Miniature EPSCs (mEPSCs) and miniature IPSCs (mIPSCs) were recorded at $-70 \mathrm{mV}$ in the presence of tetrodotoxin $(500 \mathrm{nM})$ to block action potential-driven spontaneous events. AMPAR mEPSCs were selected based on their amplitude $(>12 \mathrm{pA})$, decay time $(<3 \mathrm{~ms})$, and rise time ( $<1 \mathrm{~ms}$ ) using the MiniAnalysis program (Synaptosoft). Similarly, $\mathrm{GABA}_{\mathrm{A}}$ mIPSCs were selected for amplitude $(>12 \mathrm{pA})$, rise time $(<4$ $\mathrm{ms})$, and decay time $(<10 \mathrm{~ms})$.

The excitatory/inhibitory balance was recorded with an internal solution containing the following (in $\mathrm{mM}$ ): 132 cesium methanesulfonate, $8 \mathrm{CsCl}$, $10 \mathrm{HEPES}$, 0.6 EGTA, $4 \mathrm{Mg}$-ATP, $0.3 \mathrm{Na}$-GTP, and 10 $\mathrm{Na}$-phosphocreatine. EPSCs were recorded at the reversal potential for $\mathrm{GABA}_{\mathrm{A}}$ IPSCs $(-67 \mathrm{mV})$, and IPSCs were recorded at the reversal potential for EPSCs $(+8 \mathrm{mV})$. The $\mathrm{G}_{\mathrm{e}} / \mathrm{G}_{\mathrm{i}}$ ratio was calculated by converting the average peak current amplitude of the EPSC and the IPSC into a conductance.

Systemic drug treatment. Rats were removed from their home cage and placed individually in a clean cage. Rats were given either SB 334867 (10 $\mathrm{mg} / \mathrm{kg}$, i.p.; Tocris Bioscience) or vehicle (10\% DMSO, $20 \% \beta$-hydroxy cyclodextrin in saline), or were not given an injection (naive rats). Fifteen minutes later, rats were treated with morphine $\mathrm{HCl}(10 \mathrm{mg} / \mathrm{kg}$, i.p. ) or an equivalent volume of saline $(0.9 \% \mathrm{NaCl})$. Following injection procedures, rats were returned to their home cage and were left for $24 \mathrm{~h}$.

Surgical procedures. Sprague Dawley rats (50-60 g at the start of the experiment) were housed individually following surgical procedures. Animals were anesthetized with isoflurane and placed in a stereotaxic frame (Kopf) and bilateral cannulas (26 gauge; Plastics One) were lowered into the VTA (coordinates in $\mathrm{mm}$ : anteroposterior, -4.6 to -5.2 ; mediolateral, \pm 0.5 ; dorsoventral, -7.0 ). As a control, some animals were implanted with cannulas that only reached dorsoventral $-5.0 \mathrm{~mm}$ to test infusions outside of the VTA. Cannulas were anchored to the skull surface with dental cement and were occluded with a dummy cannula of the same length. Rats were treated postsurgically with ketoprofen $(5 \mathrm{mg} / \mathrm{kg}$, s.c.), and weights were monitored daily during the recovery period.

Intra-VTA drug infusions. During the recovery period, rats were familiarized with the infusion procedures with three habituation sessions. During these sessions, rats were transferred from their home cage to a clean cage and were left for $30 \mathrm{~min}$. Afterward, rats were handled for 5-10 min and the dummy cannula was replaced with a microinjector, cut above the length of the cannula to prevent tissue damage to the VTA. The microinjector was attached to a Hamilton syringe with tubing, and a mock infusion was performed with a microinfusion pump. The microinjector was left in place for $5 \mathrm{~min}$ before being replaced with the dummy cannula, and rats were left in the injection cage for 15 min before being returned to their home cage. On injection day, microinfusions were conducted using 33 gauge microinjectors that protruded $0.5 \mathrm{~mm}$ below the base of the guide cannula to a final dorsoventral coordinate of $7.5 \mathrm{~mm}$. SB $334867(0.3$ or $0.03 \mathrm{nmol} / 0.3 \mu \mathrm{l})$ or vehicle (50\% saline, $50 \%$ DMSO) were infused bilaterally into the VTA $(0.3 \mu \mathrm{l} /$ side at $0.1 \mu \mathrm{l} / \mathrm{min})$ with the microinfusion pump. Microinjectors were left in place for $5 \mathrm{~min}$ following the injection, at which point rats were injected systemically with morphine $(10 \mathrm{mg} / \mathrm{kg}$, i.p. $)$ or saline. Rats were then returned to their home cage and were left for $24 \mathrm{~h}$.

Data analysis. All values are expressed as the mean \pm SEM. Statistical significance was assessed using two-way or one-way ANOVA with Bonferroni post-tests. In all experiments, the sample size is expressed as $N / n$ where $N$ refers to the number of cells recorded from $n$ animals. Prism 5 software (GraphPad Software) was used to perform the statistical analysis. Figures were generated using Illustrator CS2 software (Adobe Systems). The levels of significance are indicated as follows: ${ }^{* * *} p<0.001$, ${ }^{\star *} p<0.01,{ }^{*} p<0.05$.

\section{Results}

\section{OxR1 signaling is required for morphine-induced} potentiation of excitatory inputs to VTA dopamine neurons Morphine, like other addictive drugs, induces an LTP-like potentiation of excitatory inputs to VTA dopamine neurons (Ungless et al., 2001; Saal et al., 2003; Borgland et al., 2004; Brown et al., 2010). To examine the role for orexin signaling in morphineinduced plasticity, we measured the relative contribution of AMPAR and NMDAR EPSCs $24 \mathrm{~h}$ after a single injection of morphine $(10 \mathrm{mg} / \mathrm{kg})$ or saline $(0.9 \% \mathrm{NaCl})$, with or without pretreatment with the OxR1 antagonist SB $334867(10 \mathrm{mg} / \mathrm{kg})$. 
A

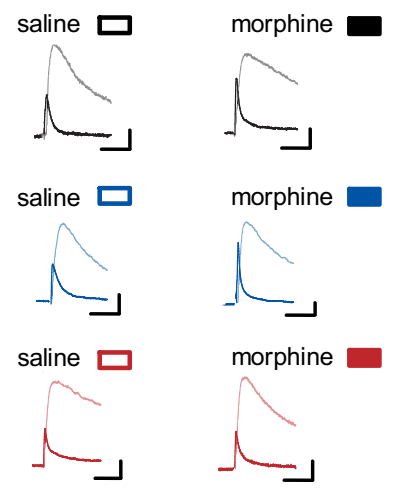

B

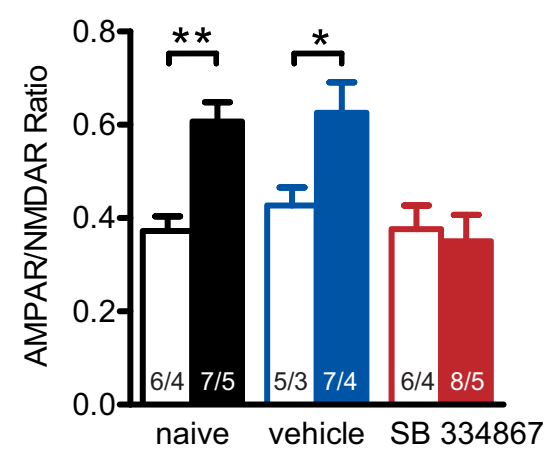

C

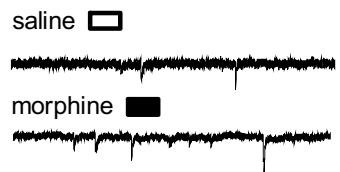

D

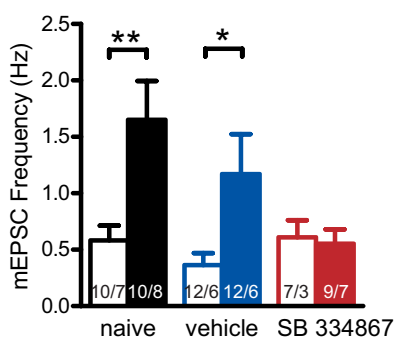

E

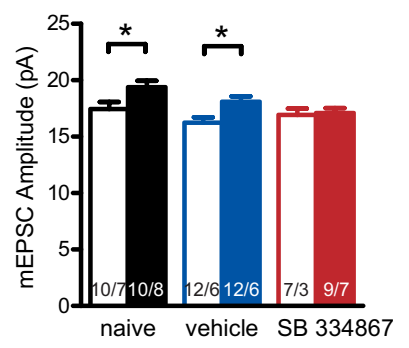

F
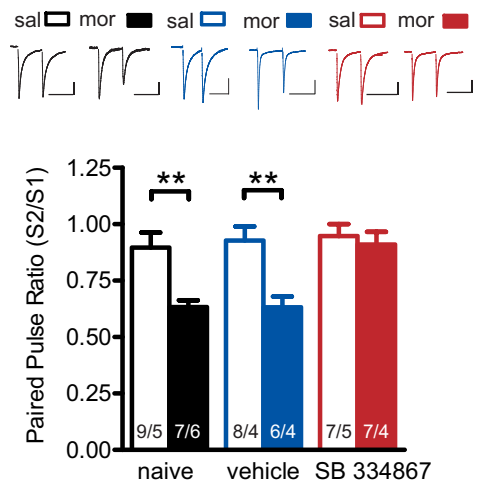

saline $\square$ morphine
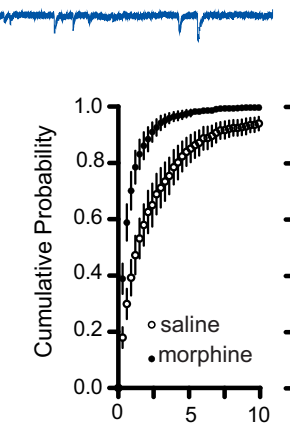

saline $\square$

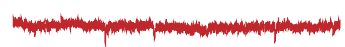

morphine $\square$

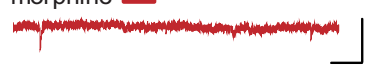

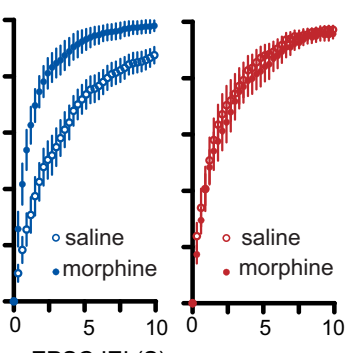

mEPSC IEI (S)

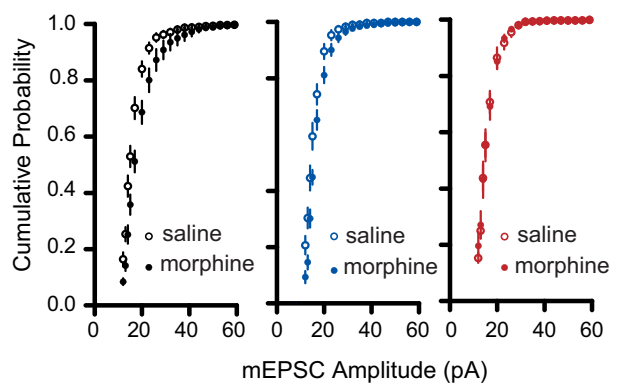

G
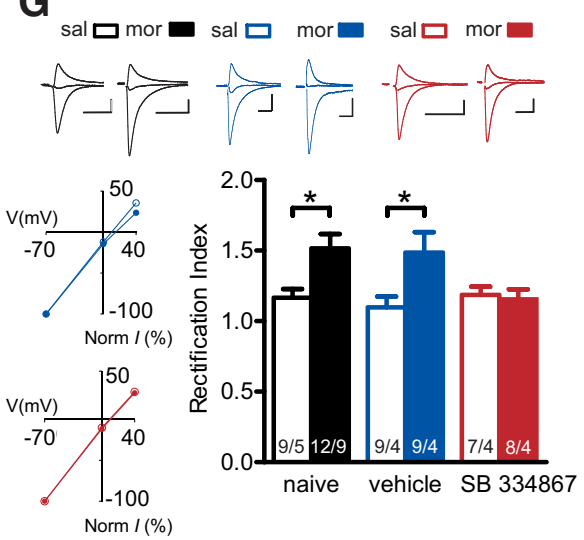

Figure 1. Systemic administration of the 0xR1 antagonist SB 334867 blocks morphine-induced potentiation of excitatory transmission onto VTA dopamine neurons. A, Example recordings of evoked NMDAR (light) and AMPAR (dark) EPSCs at $+40 \mathrm{mV}$, from VTA dopamine neurons of rats $24 \mathrm{~h}$ after exposure to morphine or saline in naive (top), vehicle-treated (middle), and SB 334867-treated (10 mg/kg; bottom) rats. Calibration: 50 pA, 20 ms. B, Treatment with morphine (10 mg/kg, filled bars), but not saline (open bars), increased the AMPAR/NMDAR ratio in naive and vehicle-treated, but not in SB 334867-treated rats $(p<0.05$,

Consistent with previous observations (Saal et al., 2003), a single injection of morphine significantly potentiated the AMPAR/ NMDAR ratio in both naive (saline, $0.4 \pm$ 0.03 ; morphine, $0.6 \pm 0.04 ; p<0.01$ ) and vehicle-treated rats [saline, $0.4 \pm 0.04$; morphine, $0.6 \pm 0.06$; $p<0.05$; Fig. $1 A, B$; two-way-ANOVA: drug (morphine vs saline) $\times$ pretreatment (naive, vehicle, $\mathrm{SB}$ 334867) interaction, $F_{(2,33)}=3.870, p=$ 0.031 ; drug, $F_{(1,33)}=10.30, p=0.003$; pretreatment, $\left.F_{(2,33)}=5.558, p=0.008\right]$. This potentiation was blocked in rats pretreated with SB $33486715 \mathrm{~min}$ before morphine exposure (saline, $0.4 \pm$ 0.05 ; morphine, $0.4 \pm 0.06 ; p>0.05$; Fig. $1 A, B)$.

To further investigate the effect of morphine on AMPARs at excitatory synapses of dopamine neurons, we recorded AMPAR mEPSCs to determine the locus of synaptic change. Morphine induced a long-lasting increase in the frequency of AMPAR mEPSCs in naive rats (saline, $0.6 \pm 0.1 \mathrm{~Hz}$; morphine, $1.6 \pm 0.3 \mathrm{~Hz}$; $p<0.01$ ) and vehicle-treated rats (saline, $0.4 \pm 0.1 \mathrm{~Hz}$; morphine, $1.2 \pm 0.3 ; p<$ $0.05)$, but not in SB 334867-treated rats (saline, $0.6 \pm 0.2 \mathrm{~Hz}$; morphine, $0.6 \pm$ $0.1 \mathrm{~Hz} ; p>0.05$; Fig. $1 C, D$; two-way ANOVA: interaction, $F_{(2,54)}=2.488, p=$ 0.093 ; drug, $F_{(1,54)}=8.861, p=0.004$; pretreatment, $\left.F_{(2,54)}=2.252, p=0.115\right)$. This increase in the probability of presynaptic glutamate release was confirmed

two-way ANOVA). C, Example traces of AMPAR mEPSCs recorded at $-70 \mathrm{mV} 24 \mathrm{~h}$ after morphine or saline treatment in naive (left), vehicle-treated (center), and SB 334867-treated (right) rats. Calibration: 50 pA, 100 ms. D, Left, AMPAR mEPSC frequency was increased in morphine-treated rats compared with saline-treated rats in naive and vehicle-treated, but not in SB 334867-treated rats ( $p<0.05$, two-way ANOVA). Right, Cumulative probability plots comparing morphine or saline exposure on mEPSCs for naive, vehicle-treated, and SB 334867-treated animals. $\boldsymbol{E}$, Left, Morphine increased AMPAR $\mathrm{mEPSC}$ amplitude compared with saline in naive and vehicletreated, but not SB 334867-treated rats ( $p<0.05$, two-way ANOVA). Right, Cumulative probability plots comparing morphine or saline exposure on mEPSC amplitude for naive, vehicle-treated, and SB 334867-treated rats. F, Morphine (filled bars) induced a paired-pulse depression of evoked AMPAR EPSCs in naive and vehicle-treated rats, but not in SB 334867-treated rats $(p<0.05$, two-way ANOVA). Inset, Sample traces of evoked AMPAR EPSC paired pulses recorded at $-70 \mathrm{mV}$. Calibration: $50 \mathrm{pA}, 20 \mathrm{~ms}$. G, Pretreatment with SB 334867 blocked a morphine-induced increase in the rectification index ( $p<0.05$, two-way ANOVA). Inset, Sample traces of AMPAR EPSCs recorded at $-70,0$, and $+40 \mathrm{mV}$ with spermine in the pipette solution. Current-voltage relationship of AMPAR EPSCS for morphine and saline in vehicle-treated and SB 334867-treated rats. Calibration: 50 pA, $10 \mathrm{~ms} . n / N=$ cells/rats. Bars represent the mean \pm SEM. ${ }^{*} p<0.05,{ }^{* *} p<$ 0.01 . 
A
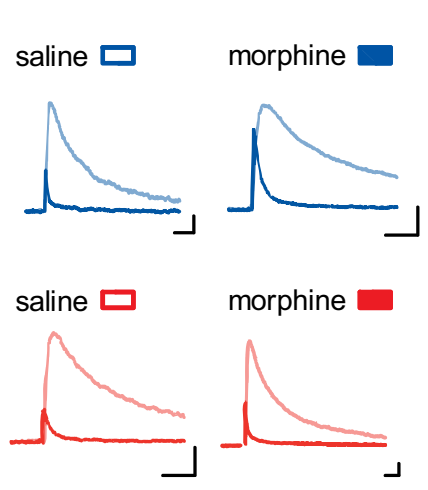

C

saline $\square$

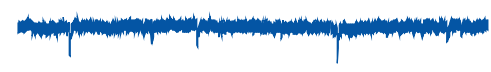

morphine

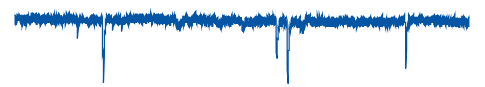

B

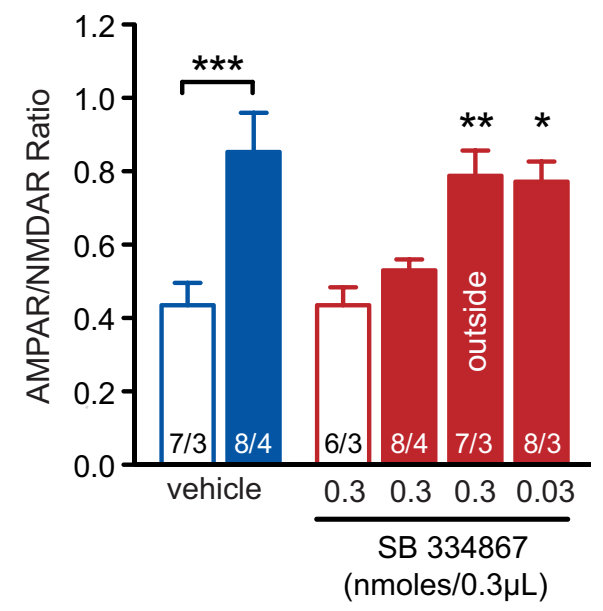

saline $\square$

morphine

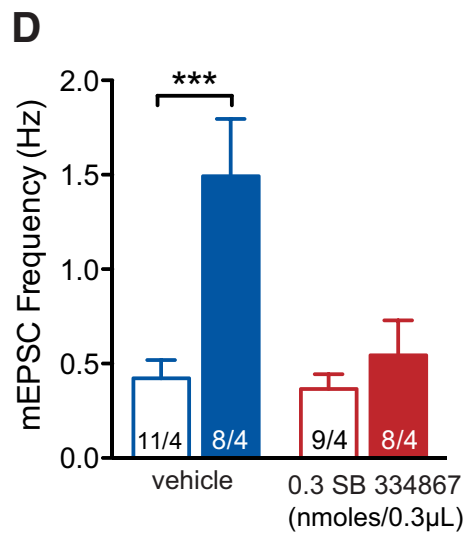

E

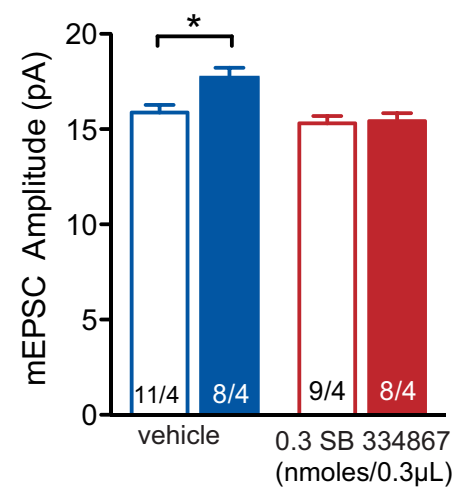

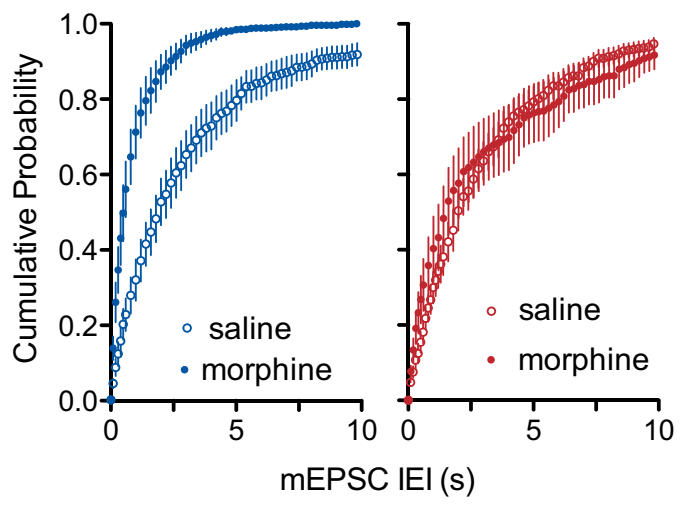

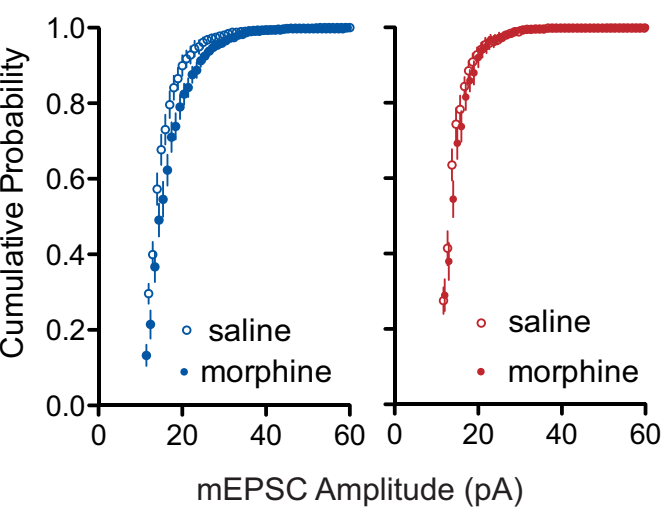

Figure 2. 0xR1 signaling in the VTA is required for morphine-induced plasticity at glutamatergic synapses. $A$, Sample traces of evoked AMPAR (dark) and NMDAR (light) EPSCs recorded at $+40 \mathrm{mV}, 24$ h after exposure to morphine or saline in rats microinfused with intra-VTA vehicle or SB 334867 rats. Calibration: 50 pA, 20 ms. $\boldsymbol{B}$, Morphine (filled bars) potentiated the AMPAR/NMDAR ratio compared with saline (open bars) in intra-VTA vehicle-treated animals, but not intra-VTA SB 334867-treated animals $(p<0.05$, two-way ANOVA). SB 334867 was ineffective when infused outside the VTA or when the dose was lowered to $0.03 \mathrm{nmol} / 0.3 \mu \mathrm{l}$. $\boldsymbol{C}$, Sample traces of AMPAR mEPSCs recorded at $-70 \mathrm{mV}, 24 \mathrm{~h}$ after morphine or saline exposure in intra-VTA vehicle-treated and with the paired-pulse ratio. Morphineinduced a paired-pulse depression in naive (saline: $0.9 \pm 0.07$; morphine: $0.6 \pm$ $0.03, p<0.01$ ) and vehicle-treated rats (saline: $0.9 \pm 0.06$; morphine: $0.6 \pm 0.05$, $p<0.01$; Fig. $1 F$ ). Morphine-induced paired-pulse depression was inhibited by SB 334867 (saline, $0.9 \pm 0.05$; morphine, $0.9 \pm 0.06$; $p>0.05$; Fig. $1 F$; two-way ANOVA: interaction, $F_{(2,38)}=3.371$, $p=0.045 ;$ drug, $F_{(1,38)}=20.37, p<$ 0.0001 ; pretreatment, $F_{(2,38)}=4.468$, $p=0.018)$.

Orexin signaling also modulated postsynaptic AMPAR effects induced by morphine exposure. Morphine treatment increased the amplitude of AMPAR mEPSCs in VTA neurons of control rats (naive: saline, $17.4 \pm 0.6 \mathrm{pA}$; morphine, $19.4 \pm 0.6 \mathrm{pA} ; p<0.05$; vehicle: saline, $16.2 \pm 0.5 \mathrm{pA}$; morphine, $18.1 \pm 0.5 \mathrm{pA}$; $p<0.05$ ), an effect that was blocked by pretreatment with SB 334867 (saline, $16.9 \pm 0.6 \mathrm{pA}$; morphine, $17.1 \pm 0.5 \mathrm{pA}$; $p>0.05$; Fig. $1 C, E$; two-way ANOVA: interaction, $F_{(2,54)}=1.583, p=0.214$; drug, $F_{(1,54)}=9.102, p=0.004$; pretreatment, $\left.F_{(2,54)}=4193, p=0.020\right)$. Because morphine treatment is associated with a change in the subunit composition of AMPARs in the VTA (Brown et al., 2010), we measured the rectification index following morphine treatment. Morphine increased the rectification index in naive rats (saline, $1.1 \pm 0.06$; morphine, $1.5 \pm 0.1 ; p<0.05)$ and vehicle-treated rats (saline, $1.1 \pm 0.08$; morphine, $1.5 \pm$ $0.1 ; p<0.05$ ), but not in those that were treated with SB 334867 (saline, $1.2 \pm 0.06$; morphine, $1.2 \pm 0.07 ; p>0.05$; Fig. $1 G$; two-way ANOVA: interaction, $F_{(2,28)}=$ 2.549, $p=0.088$; drug, $F_{(1,54)}=8.876$, $p=0.005$; pretreatment, $\left[F_{(2,48)}=1.520\right.$, $p=0.230)$. Together, these data suggest that orexin signaling is necessary for morphine-induced potentiation of presynaptic and postsynaptic efficacy of glutamatergic synapses.

$\leftarrow$

intra-VTA SB 334867-treated rats. Calibration: 50 pA, $100 \mathrm{~ms}$ $D$, Left, Morphine increased the frequency of AMPAR mEPSC relative to saline in intra-VTA vehicle-treated rats, but not intra-VTA SB-334867-treated rats $(p<0.05$, two-way ANOVA). Right, Cumulative probability plot comparing morphine and saline exposure on mEPSCs for intra-VTA vehicle- or SB 334867-treated rats. $\boldsymbol{E}$, Left, Intra-VTA SB 334867 inhibited a morphine-induced increase in the amplitude of AMPAR mEPSCS in VTA dopamine neurons ( $p<0.05$, two-way ANOVA). Right, Cumulative probability plot comparing morphine and saline exposure on mEPSC amplitude for intra-VTA vehicle- or SB 334867treated rats. $n / N=$ cells/rats. Bars represent the mean \pm SEM. ${ }^{*} p<0.05,{ }^{* *} p<0.01,{ }^{* * *} p<0.001$. 
A

saline $\square$

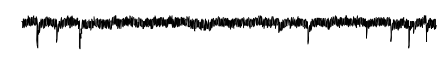

morphine

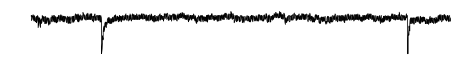

B

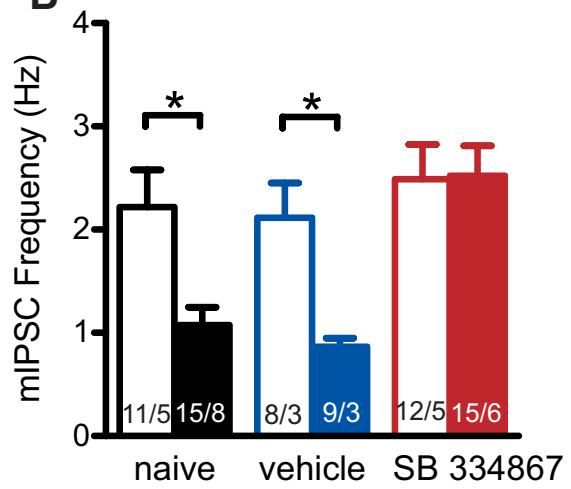

C

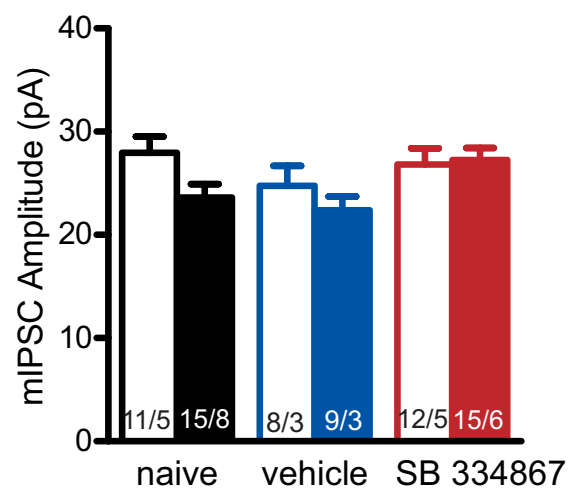

saline

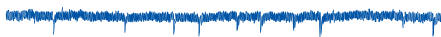

morphine saline

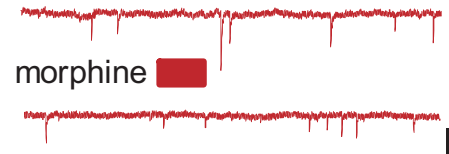

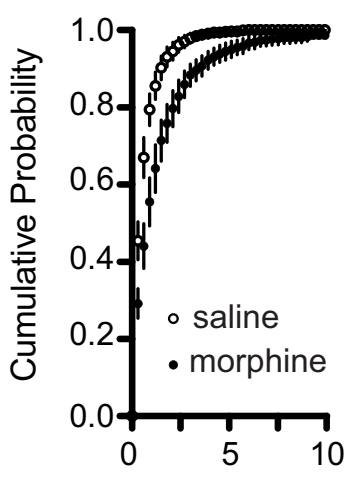

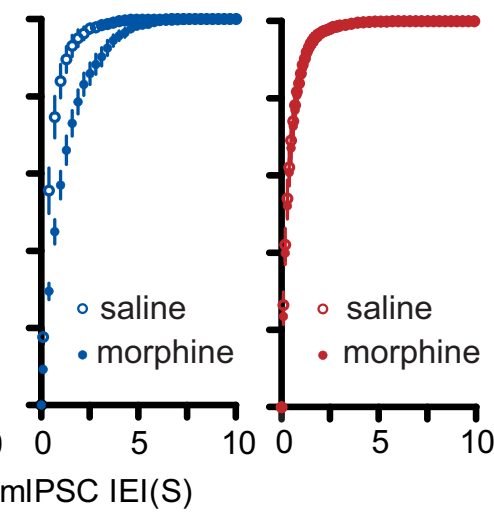

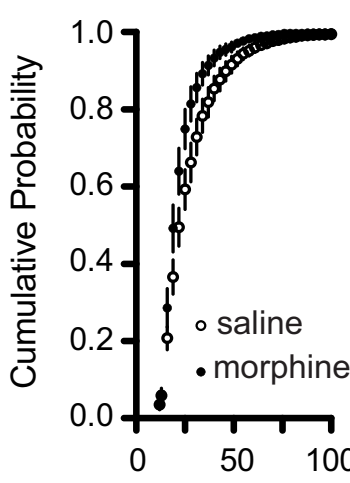
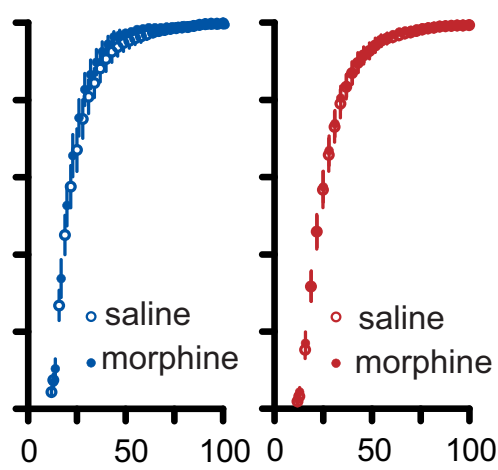

mIPSC Amplitude ( $p A)$

Figure 3. Morphine decreases the probability of presynaptic GABA release in an 0xR1-dependent manner. $A$, Example recordings of $G A B A_{A} \mathrm{mIPSCs}$ recorded at - $70 \mathrm{mV}$, $24 \mathrm{~h}$ after exposure to morphine or saline in naive, vehicle-treated, or SB 334867-treated rats. Calibration: 50 pA, $200 \mathrm{~ms}$. B, Left, Morphine (filled bars) decreased the frequency of GABA $\mathrm{mIPSC}_{\mathrm{A}}$ relative to saline (open bars) in naive and vehicle-treated rats, but not in SB 334867-treated rats ( $p<0.05$, two-way ANOVA). Right, Cumulative probability plots comparing morphine or saline exposure on mIPSC for

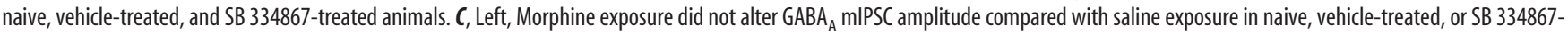
treated animals ( $p>0.05$, two-way ANOVA). Right, Cumulative probability plots comparing morphine or saline exposure on mIPSC amplitude for naive, vehicle-treated, and SB 334867-treated animals. $n / N=$ cells/rats. Bars represent mean \pm SEM. ${ }^{*} p<0.05$.

Orexin signals locally in the VTA to mediate morphineinduced potentiation of excitatory synaptic transmission OxR1 is expressed widely throughout the brain (Trivedi et al., 1998; Marcus et al., 2001). Therefore, systemic administration of SB 334867 precluded identification of the site of action of orexin in modulating morphine-induced plasticity. Because microinfusion of SB 334867 into the VTA inhibits the reinstatement of morphine-induced conditioned place preference (CPP; Narita et al., 2006), we hypothesized that orexin was signaling locally in the VTA to mediate morphine-induced potentiation of glutamatergic synaptic transmission. To test this, we implanted rats with a bilateral cannula aimed at the VTA and microinfused SB 334867 locally. In rats that received vehicle infusions into the VTA, systemic morphine administration increased the AMPAR/NMDAR ratio compared with saline (saline, $0.4 \pm 0.06$; morphine, $0.8 \pm$ $0.1 ; p<0.01$; Fig. $2 A, B)$. This effect of morphine was blocked by an intra-VTA infusion of SB $334867(0.3 \mathrm{nmol} / 0.3 \mu \mathrm{l}$; saline,
$0.4 \pm 0.05$; morphine, $0.5 \pm 0.03 ; p>0.05$; Fig. $2 A, B$; two-way ANOVA: interaction, $F_{(1,25)}=5.122, p=0.033$; drug, $F_{(1,25)}=$ $12.89, p=0.001$; pretreatment, $\left.F_{(1,25)}=5.103, p=0.033\right)$. However, SB 334867 did not block a morphine-induced increase in the AMPAR/NMDAR ratio when infused outside the VTA (morphine, $0.8 \pm 0.07)$ or when the dose was 10 -fold lower $(0.03$ nmol/ $0.3 \mu \mathrm{l}$; morphine, $0.8 \pm 0.05$; one-way ANOVA: $F_{(3,25)}=$ $10.85, p<0.0001)$.

To test whether intra-VTA orexin signaling modulates morphine-induced presynaptic or postsynaptic plasticity at excitatory synapses, we recorded AMPAR mEPSCs. Morphine increased the frequency of AMPAR mEPSCs compared with saline in intra-VTA vehicle-treated (saline, $0.4 \pm 0.1 \mathrm{~Hz}$; morphine, $1.5 \pm 0.3 \mathrm{~Hz} ; p<0.001)$, but not SB 334867-treated rats $(0.3$ $\mathrm{nmol} / 0.3 \mu \mathrm{l}$; saline, $0.4 \pm 0.08 \mathrm{~Hz}$; morphine, $0.5 \pm 0.2 \mathrm{~Hz} ; p>$ 0.05; Fig. $2 C, D$; two-way ANOVA: interaction, $F_{(1,32)}=6.551$, $p=0.015$; drug, $F_{(1,32)}=12.84, p=0.001$; pretreatment, $F_{(1,32)}=$ 
8.289, $p=0.007)$. Similarly, morphine increased AMPAR mEPSC amplitude in an orexin-dependent manner (two-way ANOVA: interaction, $F_{(1,32)}=3.685, p=$ 0.064 ; drug, $F_{(1,32)}=4.894, p=0.034$; pretreatment, $\left.F_{(1,32)}=10.26, p=0.003\right)$. In morphine-exposed rats, mEPSC amplitude was increased in intra-VTA vehicletreated (saline, $15.9 \pm 0.4 \mathrm{pA}$; morphine, $17.7 \pm 0.5 \mathrm{pA} ; p<0.05)$, but not in intraVTA SB 334867-treated rats $(0.3 \mathrm{nmol} /$ $0.3 \mu \mathrm{l}$; saline, $15.3 \pm 0.4 \mathrm{pA}$; morphine, $15.4 \pm 0.4 \mathrm{pA} ; p>0.05$; Fig. $2 C, E)$. Together, these results suggest that orexin signaling in the VTA is necessary for morphine-induced presynaptic and postsynaptic potentiation at excitatory synapses onto dopamine neurons.

\section{OxR1 signaling is required for a morphine-induced decrease in presynaptic GABA release}

Short-term morphine administration increases VTA dopamine neuronal activity by way of disinhibition resulting from $\mu$-opioid receptor activation on GABAergic inputs to dopamine neurons (Di Chiara and Imperato, 1988; Johnson and North, 1992; Jalabert et al., 2011). Moreover, morphine has long-term effects on GABA transmission in the VTA (Nugent et al., 2007; Dacher and Nugent, 2011). Therefore, we recorded $\mathrm{GABA}_{\mathrm{A}}$ mIPSCs in VTA dopamine neurons $24 \mathrm{~h}$ after a single morphine exposure to assess whether orexin signaling had a role in morphineinduced plasticity at GABAergic synapses in the VTA. Morphine treatment decreased $\mathrm{GABA}_{\mathrm{A}}$ mIPSC frequency on to dopamine neurons of control rats (naive rats: saline, $2.2 \pm 0.4 \mathrm{~Hz}$; morphine, $1.1 \pm$ $0.2 \mathrm{~Hz} ; p<0.05$; vehicle-treated rats: saline, $2.1 \pm 0.3 \mathrm{~Hz}$; morphine, $0.9 \pm 0.08$ $\mathrm{Hz} ; \quad p<0.05$; Fig. $3 A-C$; two-way ANOVA: interaction, $F_{(2,62)}=3.262, p=$ 0.045; drug, $\left.F_{(1,62)}=11.19, p=0.001\right]$; pretreatment, $\left[F_{(2,62)}=7.566, p=0.001\right)$. However, SB 334867 inhibited morphineinduced suppression of mIPSC frequency (saline, $2.5 \pm 0.3 \mathrm{~Hz}$; morphine, $2.5 \pm 0.3$

$\mathrm{Hz} ; p>0.05$; Fig. $3 A-C)$. There was no effect of morphine on $\mathrm{GABA}_{\mathrm{A}}$ mIPSC amplitude (two-way ANOVA: interaction, $\left[F_{(2,62)}=\right.$ $1.493, p=0.232$; drug, $F_{(1,62)}=3.011, p=0.088$; pretreatment, $F_{(2,62)}=2.537, p=0.088$; Fig. $\left.3 A, D, E\right)$.

OxR1 activation in the VTA is required for a morphineinduced decrease in the probability of presynaptic GABA release

We next examined whether the morphine-induced decrease in the probability of GABA release was mediated by $\mathrm{OxR} 1$ activation within the VTA. Morphine decreased $\mathrm{GABA}_{\mathrm{A}}$ mIPSC frequency in intra-VTA vehicle-treated rats (saline, $2.3 \pm 0.4 \mathrm{~Hz}$; morphine, $1.2 \pm 0.1 ; p<0.05)$, but not in those that received intra-VTA SB

A

B
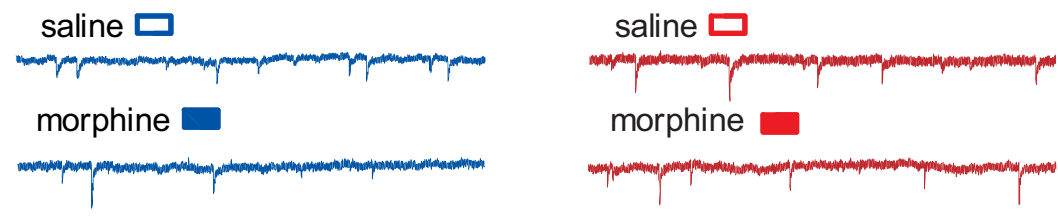

morphine
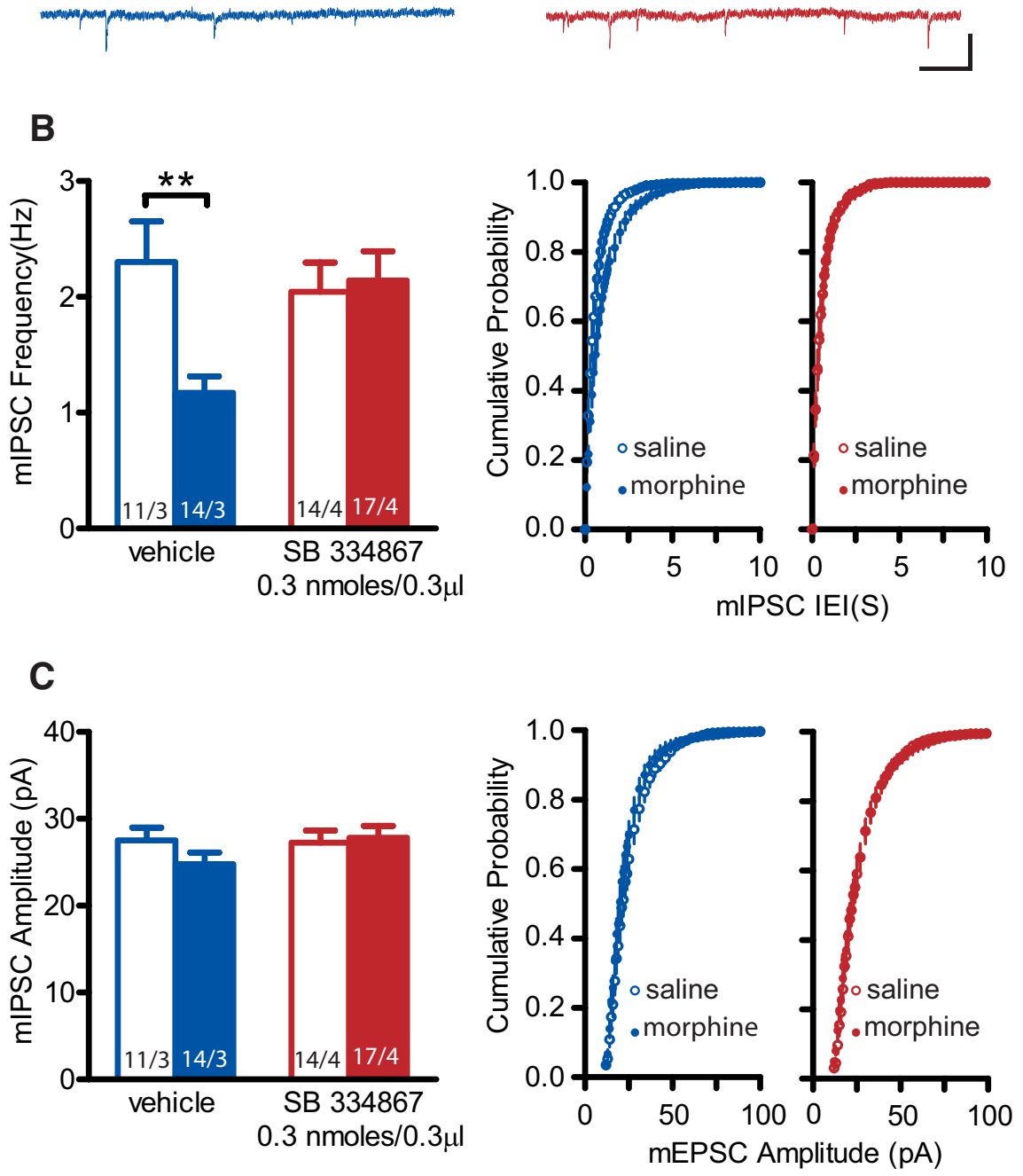

Figure 4. OxR1 signaling in the VTA is necessary for a morphine-induced suppression of presynaptic GABA release. $A$, Sample recordings of GABA ${ }_{A}$ mIPSCs at $-70 \mathrm{mV}$, from rats that were exposed to morphine or saline after pretreatment with intra-VTA relative to saline (open bars) in intra-VTA vehicle-treated rats, but not intra-VTA SB 334867-treated rats ( $p<0.05$, two-way Ay ANOVA). Right, Cumulative probability plots comparing morphine and saline exposure on mIPSC amplitude for intra-VTA vehicle-treated rats or SB 334867-treated rats. $n / N=$ cells/rats. Bars represent the mean \pm SEM. ${ }^{* *} p<0.01$.

$334867(0.3 \mathrm{nmol} / 0.3 \mu \mathrm{l}$; saline, $2.0 \pm 0.3 \mathrm{~Hz}$; morphine, $2.1 \pm$ $0.3 ; p>0.05$; Fig. $4 A, B$; two-way ANOVA: interaction, $F_{(1,52)}=$ 5.845, $p=0.019$; drug, $F_{(1,52)}=4.118, p=0.047$; pretreatment, $\left.F_{(1,52)}=1.951, p=0.169\right)$. There was no effect of morphine treatment on $\mathrm{GABA}_{\mathrm{A}}$ mIPSC amplitude in either group (twoway ANOVA: interaction, $F_{(1,52)}=1.316, p=0.256$; drug, $F_{(1,52)}=0.588, p=0.447$; pretreatment, $F_{(1,52)}=0.955, p=$ 0.333; Fig. $4 A, C)$.

Morphine alters the synaptic excitation/inhibition balance in an OxR1-dependent manner

Our results demonstrate that a single morphine exposure induces a simultaneous OxR1-dependent increase in glutamate transmission and a decrease in GABA transmission on to VTA dopamine 
A

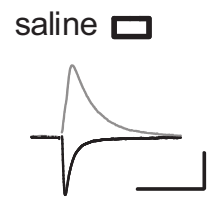

saline $\square$

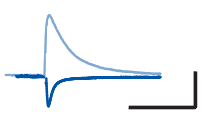

saline $\square$
B

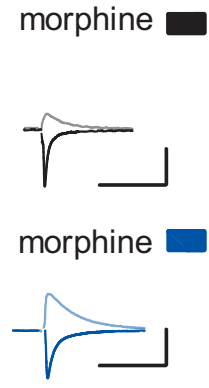

morphine

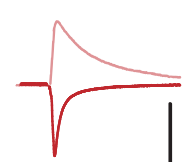

C
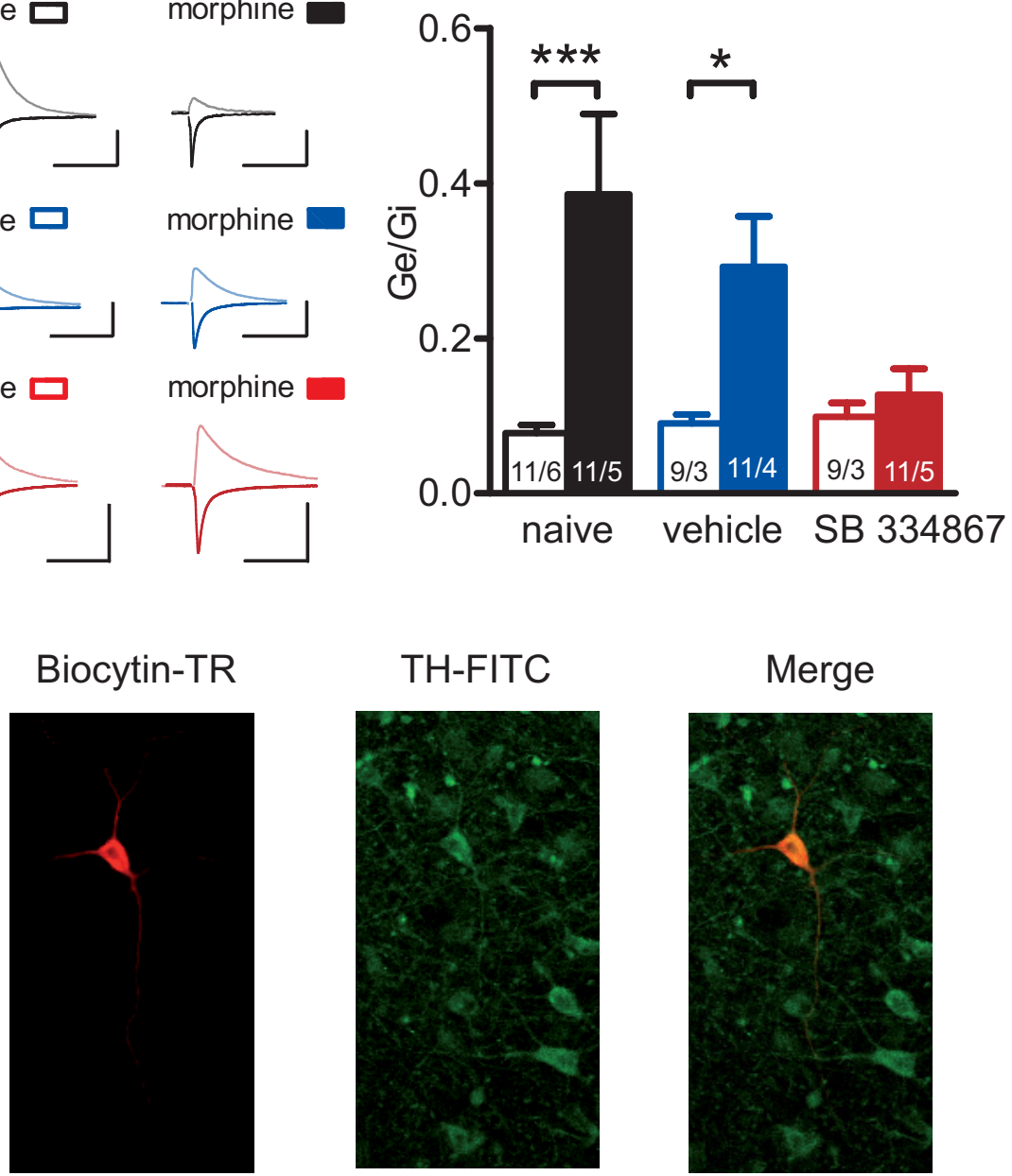

Figure 5. 0xR1 signaling is required for a morphine-induced shift in the balance of excitatory and inhibitory synaptic transmis sion onto dopamine neurons. $A$, Example recordings of EPSCs (dark) at $-67 \mathrm{mV}$, and IPSCs (light) at $+8 \mathrm{mV}$ from VTA dopamine neurons in naive, vehicle-treated, and SB 334867-treated animals. Calibration: 200 pA, 20 ms. B, Morphine (filled), compared with saline (open), induced a switch in the ratio of excitatory and inhibitory conductances onto dopamine neurons from naive or vehicle-treated animals. This shift was inhibited by systemic SB 334867 ( $p<0.05$, two-way ANOVA). C, SB 334867 inhibited the morphine-induced increased $G_{e} / G_{i}$ ratio in seven of nine identified tyrosine hydroxylase (TH)-positive neurons. TH was labeled with anti-TH antibodies and FITC. Biocytin was labeled with streptavidin-conjugated Texas Red. $n / N=$ cells/rats. Bars represent the mean \pm SEM. ${ }^{*} p<0.05,{ }^{* * *} p<0.001$.

neurons. By acting at both excitatory and inhibitory synapses, orexin may drive a morphine-induced shift in the excitatory/ inhibitory $\left(G_{e} / G_{i}\right)$ balance of synaptic inputs on to dopamine neurons. To verify this, we recorded locally evoked EPSCs and IPSCS onto the same cell. EPSCs were recorded at the IPSC reversal potential $(-67 \mathrm{mV})$, and IPSCs were recorded at the EPSC reversal potential $(+8 \mathrm{mV})$. Morphine induced a shift in the $\mathrm{G}_{\mathrm{e}} / \mathrm{G}_{\mathrm{i}}$ balance onto dopamine neurons from naive rats (saline, $0.08 \pm 0.01 ;$ morphine, $0.4 \pm 0.1 ; p<0.05)$ and vehicle-treated rats (saline, $0.09 \pm 0.01$; morphine, $0.3 \pm 0.07 ; p<0.05$; Fig. $5 A, B$ ), but not in those that were treated with SB 334867 (saline, $0.1 \pm 0.02$; morphine, $0.1 \pm 0.03 ; p>0.05$; Fig. $5 A, B$; two-way ANOVA: interaction, $F_{(2,56)}=3.184, p=0.049$; drug, $F_{(1,56)}=$ 15.37, $p=0.0002$; pretreatment, $\left.F_{(2,56)}=2.338, p=0.106\right)$. Together, these data suggest that orexin signaling is necessary for a morphine-induced shift in the balance of inhibitory and excitatory control of dopamine neurons.

\section{Discussion}

Here, we establish a critical role for orexin signaling in morphine-induced synaptic plasticity in the VTA. Both systemic and intra-VTA administration of the OxR1 antagonist SB 334867 inhibited morphineinduced potentiation of excitatory synaptic transmission. Additionally, SB 334867 blocked a long-lasting decrease in the probability of presynaptic GABA release at inhibitory synapses onto dopamine neurons. Last, OxR1 signaling was required for a morphine-induced shift in the balance of excitatory and inhibitory inputs to dopamine neurons. These data provide further evidence that orexin signaling in the VTA plays a critical role in druginduced plasticity of dopamine neurons.

Previous work (Saal et al., 2003; Brown et al., 2010) has demonstrated that a single morphine exposure increases the AMPAR/ NMDAR ratio and promotes the insertion of GluA2-lacking AMPARs to the postsynaptic site, as revealed by an increase in the rectification index. Not only have we replicated these results, but we have demonstrated that morphine also increases the probability of presynaptic glutamate release, and that both presynaptic and postsynaptic changes induced by morphine to enhance synaptic efficacy onto dopamine neurons require OxR1 signaling in the VTA. Because overexpression of GluA1 subunits in the VTA potentiates morphine reward in a CPP task (Carlezon et al., 1997), orexin-dependent morphineinduced plasticity at excitatory synapses likely contributes to learning the association between context and the drug experience. Consistent with this, intra-VTA administration of an orexin receptor antagonist inhibits morphine CPP (Narita et al., 2006; Harris et al., 2007). Druginduced plasticity and changes in AMPAR subunit composition have previously been attributed to activation of dopamine $\mathrm{D}_{5}$ receptors and the $\mathrm{cAMP}$-dependent protein kinase A signaling pathway (Argilli et al., 2008; Brown et al., 2010). Because the effects of orexin in the VTA are dependent on protein kinase C signaling (Borgland et al., 2006; Narita et al., 2007), OxR1 likely represents an alternative mechanism for drug-induced synaptic plasticity. Interestingly, both $\mathrm{OxR} 1$ and $\mathrm{D}_{5}$ receptor signaling can potentiate NMDAR receptor currents in the VTA, albeit through different mechanisms (Borgland et al., 2006, 2009; Schilström et al., 2006). Because NMDAR activation is required for druginduced plasticity (Ungless et al., 2001; Argilli et al., 2008; Engblom et al., 2008), OxR1 and $\mathrm{D}_{5}$ receptors may act cooperatively to enhance NMDAR signaling and to promote drug-induced synaptic changes in the VTA. Exposure to morphine also induced an OxR1-dependent increase in the probability of presynaptic glutamate release. Orexin-induced increases in glutamate release have previously been observed in multiple brain regions, includ- 
ing the VTA (van den Pol et al., 1998; Burlet et al., 2002; Li et al., 2002; Smith et al., 2002; Lambe and Aghajanian, 2003; Borgland et al., 2006, 2009). Increased glutamate release probability may reflect a mechanism additional to postsynaptic trafficking of AMPARs to further enhance synaptic efficacy cis- or trans-synaptically.

In addition to morphine action at excitatory synapses, we observed that morphine induces an OxR1-dependent decrease in the probability of GABA release. Previous work has demonstrated that morphine modulates GABAergic synapses onto VTA dopamine neurons. A single exposure to morphine blocks the induction of $\mathrm{LTP}_{\mathrm{GABA}}$, and likely occludes GABAergic long-term depression $\left(\mathrm{LTD}_{\mathrm{GABA}}\right)$ onto dopamine neurons (Nugent et al., 2007; Dacher and Nugent, 2011; Graziane et al., 2013). LTD requires the activation of postsynaptic dopamine $\mathrm{D}_{2}$ receptors (Dacher and Nugent, 2011). Here, we propose a novel mechanism by which orexin signaling in the VTA facilitates a morphine-induced inhibition of GABA release. Future work will need to determine the mechanism by which orexin signaling can modulate GABAergic synapses, although preliminary studies (Baimel et al., 2015) have indicated that orexin induces an endocannabinoid-mediated inhibition of GABA release onto dopamine neurons.

Rapid modulation of the $G_{\mathrm{e}} / \mathrm{G}_{\mathrm{i}}$ is important for optimal information processing (Sarti et al., 2013). Here we demonstrate that orexin facilitates the morphine-induced shift from inhibitory to excitatory influence on dopaminergic neurons. Because the balance of excitatory and inhibitory inputs of dopamine neurons is one of the key regulators of dopamine neuron activity (Floresco et al., 2003), this shift likely reflects a mechanism by which orexin can modulate the output of dopamine neurons in response to reward-predictive cues (Harris et al., 2005). The ability of orexin to increase glutamate transmission in parallel with a decrease in GABA transmission suggests an important role for orexin in gating the output of dopamine neurons.

How morphine exposure induces orexin release remains to be determined. Orexin neurons express $\mu$-opioid receptors (Georgescu et al., 2003) and are c-Fos activated with morphine administration (Harris et al., 2005, 2007; Richardson and Aston-Jones, 2012) or withdrawal (Georgescu et al., 2003). Orexin neurons that project to the VTA, but not those that project to the locus ceruleus, are activated by in vivo exposure to morphine in proportion to the level of CPP (Richardson and Aston-Jones, 2012). Furthermore, OxR1 antagonists reduce heroin self-administration and cueinduced reinstatement of opioid seeking (Smith and Aston-Jones, 2012), suggesting that increased orexin in the VTA is required for opioid seeking. Consistent with this, orexin A in the VTA is sufficient to reinstate drug seeking (Harris et al., 2005).

In contrast to these studies, a short-term (30 s) morphine application to LH slices has direct inhibitory effects on orexin neuronal activity (Li and van den Pol, 2008). Because orexin neurons are a heterogeneous cell population, and only $\sim 50 \%$ of orexin cells express high levels of $\mu$-opioid receptor immunoreactivity (Georgescu et al., 2003), opioids like morphine may differentially regulate orexin neurons that project to different brain areas. For example, opioid-induced inhibition of orexin neurons may be restricted to those neurons that project to arousal-related brain areas and thus mediate the sedating effects of morphine exposure. Alternatively, orexin neurons may be activated upon removal of morphine inhibition, potentially leading to increased orexin release in the VTA. Further research is required to test these possibilities.

In summary, we propose a novel role for orexin signaling in morphine-induced plasticity at both glutamate and GABA syn- apses in the VTA. Morphine enhances excitatory synaptic efficacy onto VTA dopamine neurons by way of an orexin-dependent increase in presynaptic glutamate release, and a postsynaptic increase in AMPAR function. Moreover, orexin facilitated a long-term decrease in presynaptic GABA release to dopamine neurons. Finally, orexin signaling was required for a shift in the balance of excitatory and inhibitory control of dopamine neurons. Together, these findings provide novel insights into how orexin gates drug-induced plasticity in the VTA.

\section{References}

Adamantidis AR, Zhang F, Aravanis AM, Deisseroth K, de Lecea L (2007) Neural substrates of awakening probed with optogenetic control of hypocretin neurons. Nature 450:420-424. CrossRef Medline

Argilli E, Sibley DR, Malenka RC, England PM, Bonci A (2008) Mechanism and time course of cocaine-induced long-term potentiation in the ventral tegmental area. J Neurosci 28:9092-9100. CrossRef Medline

Baimel C, Bartlett SE, Chiou LC, Lawrence AJ, Muschamp JW, Patkar O, Tung LW, Borgland SL (2015) Orexin/hypocretin role in reward: implications for opioid and other addictions. Br J Pharmacol 172:334-348. CrossRef Medline

Borgland SL, Malenka RC, Bonci A (2004) Acute and chronic cocaineinduced potentiation of synaptic strength in the ventral tegmental area: electrophysiological and behavioral correlates in individual rats. J Neurosci 24:7482-7490. CrossRef Medline

Borgland SL, Taha SA, Sarti F, Fields HL, Bonci A (2006) Orexin A in the VTA Is critical for the induction of synaptic plasticity and behavioral sensitization to cocaine. Neuron 49:589-601. CrossRef Medline

Borgland SL, Chang SJ, Bowers MS, Thompson JL, Vittoz N, Floresco SB, Chou J, Chen BT, Bonci A (2009) Orexin A/hypocretin-1 selectively promotes motivation for positive reinforcers. J Neurosci 29:11215-11225. CrossRef Medline

Brown MT, Bellone C, Mameli M, Labouèbe G, Bocklisch C, Balland B, Dahan L, Luján R, Deisseroth K, Lüscher C (2010) Drug-driven AMPA receptor redistribution mimicked by selective dopamine neuron stimulation PLoS One 5:e15870. CrossRef Medline

Burlet S, Tyler CJ, Leonard CS (2002) Direct and indirect excitation of laterodorsal tegmental neurons by hypocretin/orexin peptides: implications for wakefulness and narcolepsy. J Neurosci 22:2862-2872. Medline

Carlezon WA Jr, Boundy VA, Haile CN, Lane SB, Kalb RG, Neve RL, Nestler EJ (1997) Sensitization to morphine induced by viral-mediated gene transfer. Science 277:812-814. CrossRef Medline

Dacher M, Nugent FS (2011) Morphine-induced modulation of LTD at GABAergic synapses in the ventral tegmental area. Neuropharmacology 61:1166-1171. CrossRef Medline

de Lecea L, Kilduff TS, Peyron C, Gao X, Foye PE, Danielson PE, Fukuhara C, Battenberg EL, Gautvik VT, Bartlett FS 2nd, Frankel WN, van den Pol AN, Bloom FE, Gautvik KM, Sutcliffe JG (1998) The hypocretins: hypothalamusspecific peptides with neuroexcitatory activity. Proc Natl Acad Sci U S A 95: 322-327. CrossRef Medline

Di Chiara G, Imperato A (1988) Opposite effects of mu and kappa opiate agonists on dopamine release in the nucleus accumbens and in the dorsal caudate of freely moving rats. J Pharmacol Exp Ther 244:1067-1080. Medline

Engblom D, Bilbao A, Sanchis-Segura C, Dahan L, Perreau-Lenz S, Balland B, Parkitna JR, Luján R, Halbout B, Mameli M, Parlato R, Sprengel R, Lüscher C, Schütz G, Spanagel R (2008) Glutamate receptors on dopamine neurons control the persistence of cocaine seeking. Neuron 59:497508. CrossRef Medline

España RA, Melchior JR, Roberts DCS, Jones SR (2010) Hypocretin $1 /$ orexin $\mathrm{A}$ in the ventral tegmental area enhances dopamine responses to cocaine and promotes cocaine self-administration. Psychopharmacology (Berl) 214:415-426. CrossRef Medline

Floresco SB, West AR, Ash B, Moore H, Grace AA (2003) Afferent modulation of dopamine neuron firing differentially regulates tonic and phasic dopamine transmission. Nat Neurosci 6:968-973. CrossRef Medline

Gantz SC, Bunzow JR, Williams JT (2013) Spontaneous inhibitory synaptic currents mediated by a G protein-coupled receptor. Neuron 78:807-812. CrossRef Medline

Georgescu D, Zachariou V, Barrot M, Mieda M, Willie JT, Eisch AJ, Yanagisawa M, Nestler EJ, DiLeone RJ (2003) Involvement of the lateral hy- 
pothalamic peptide orexin in morphine dependence and withdrawal. J Neurosci 23:3106-3111. Medline

Graziane NM, Polter AM, Briand LA, Pierce RC, Kauer JA (2013) Kappa opioid receptors regulate stress-induced cocaine seeking and synaptic plasticity. Neuron 77:942-954. CrossRef Medline

Harris GC, Wimmer M, Aston-Jones G (2005) A role for lateral hypothalamic orexin neurons in reward seeking. Nature 437:556-559. CrossRef Medline

Harris GC, Wimmer M, Randall-Thompson JF, Aston-Jones G (2007) Lateral hypothalamic orexin neurons are critically involved in learning to associate an environment with morphine reward. Behav Brain Res 183: 43-51. CrossRef Medline

Hyman SE, Malenka RC, Nestler EJ (2006) Neural mechanisms of addiction: the role of reward-related learning and memory. Annu Rev Neurosci 29:565-598. CrossRef Medline

Jalabert M, Bourdy R, Courtin J, Veinante P, Manzoni OJ, Barrot M, Georges F (2011) Neuronal circuits underlying acute morphine action on dopamine neurons. Proc Natl Acad Sci U S A 108:16446-16450. CrossRef Medline

Johnson SW, North RA (1992) Opioids excite dopamine neurons by hyperpolarization of local interneurons. J Neurosci 12:483-488. Medline

Kauer JA, Malenka RC (2007) Synaptic plasticity and addiction. Nat Rev Neurosci 8:844-858. CrossRef Medline

Korotkova TM, Sergeeva OA, Eriksson KS, Haas HL, Brown RE (2003) Excitation of ventral tegmental area dopaminergic and nondopaminergic neurons by orexins/hypocretins. J Neurosci 23:7-11. Medline

Lambe EK, Aghajanian GK (2003) Hypocretin (orexin) induces calcium transients in single spines postsynaptic to identified thalamocortical boutons in prefrontal slice. Neuron 40:139-150. CrossRef Medline

Li Y, van den Pol AN (2008) $\mu$-Opioid receptor-mediated depression of the hypothalamic hypocretin/orexin arousal system. J Neurosci 28:28142819. CrossRef Medline

Li Y, Gao XB, Sakurai T, van den Pol AN (2002) Hypocretin/orexin excites hypocretin neurons via a local glutamate neuron-a potential mechanism for orchestrating the hypothalamic arousal system. Neuron 36:11691181. CrossRef Medline

Lüscher C, Ungless MA (2006) The mechanistic classification of addictive drugs. PLoS Med 3:e437. CrossRef Medline

Marcus JN, Aschkenasi CJ, Lee CE, Chemelli RM, Saper CB, Yanagisawa M, Elmquist JK (2001) Differential expression of orexin receptors 1 and 2 in the rat brain. J Comp Neurol 435:6-25. CrossRef Medline

Narita M, Nagumo Y, Hashimoto S, Narita M, Khotib J, Miyatake M, Sakurai T, Yanagisawa M, Nakamachi T, Shioda S, Suzuki T (2006) Direct involvement of orexinergic systems in the activation of the mesolimbic dopamine pathway and related behaviors induced by morphine. J Neurosci 26:398-405. CrossRef Medline

Narita M, Nagumo Y, Miyatake M, Ikegami D, Kurahashi K, Suzuki T (2007) Implication of protein kinase $\mathrm{C}$ in the orexin-induced elevation of extracellular dopamine levels and its rewarding effect. Eur J Neurosci 25:15371545. CrossRef Medline

Niehaus JL, Murali M, Kauer JA (2010) Drugs of abuse and stress impair LTP at inhibitory synapses in the ventral tegmental area. Eur J Neurosci 32:108-117. CrossRef Medline

Nugent FS, Penick EC, Kauer JA (2007) Opioids block long-term potentiation of inhibitory synapses. Nature 446:1086-1090. CrossRef Medline

Rao Y, Mineur YS, Gan G, Wang AH, Liu ZW, Wu X, Suyama S, de Lecea L, Horvath TL, Picciotto MR, Gao XB (2013) Repeated in vivo exposure of cocaine induces long-lasting synaptic plasticity in hypocretin/orexinproducing neurons in the lateral hypothalamus in mice. J Physiol 591: 1951-1966. CrossRef Medline

Richardson KA, Aston-Jones G (2012) Lateral hypothalamic orexin/ hypocretin neurons that project to the ventral tegmental area are differentially activated with morphine preference. J Neurosci 32:3809-3817. CrossRef Medline

Saal D, Dong Y, Bonci A, Malenka RC (2003) Drugs of abuse and stress trigger a common synaptic adaptation in dopamine neurons. Neuron 37:577-582. CrossRef Medline

Sakurai T, Amemiya A, Ishii M, Matsuzaki I, Chemelli RM, Tanaka H, Williams SC, Richardson JA, Kozlowski GP, Wilson S, Arch JR, Buckingham RE, Haynes AC, Carr SA, Annan RS, McNulty DE, Liu WS, Terrett JA, Elshourbagy NA, Bergsma DJ, et al. (1998) Orexins and orexin receptors: a family of hypothalamic neuropeptides and G protein-coupled receptors that regulate feeding behavior. Cell 92:573-585. CrossRef Medline

Sarti F, Zhang Z, Schroeder J, Chen L (2013) Rapid suppression of inhibitory synaptic transmission by retinoic acid. J Neurosci 33:11440-11450. CrossRef Medline

Schilström B, Yaka R, Argilli E, Suvarna N, Schumann J, Chen BT, Carman M, Singh V, Mailliard WS, Ron D, Bonci A (2006) Cocaine enhances NMDA receptor-mediated currents in the ventral tegmental area vid dopamine $\mathrm{D}_{5}$ receptor-dependent redistribution of NMDA receptors. J Neurosci 26:85498558. CrossRef Medline

Smith BN, Davis SF, Van Den Pol AN, Xu W (2002) Selective enhancement of excitatory synaptic activity in the rat nucelus tractus solitarius by hypocretin 2. Neuroscience 115:707-714. CrossRef Medline

Smith RJ, Aston-Jones G (2012) Orexin/hypocretin 1 receptor antagonist reduces heroin self-administration and cue-induced heroin seeking. Eur J Neurosci 35:798-804. CrossRef Medline

Thompson JL, Borgland SL (2013) Presynaptic leptin action suppresses excitatory synaptic transmission onto ventral tegmental area dopamine neurons. Biol Psychiatry 73:860-868. CrossRef Medline

Trivedi P, Yu H, MacNeil DJ, Van der Poeg LH, Guan XM (1998) Distribution of orexin receptor mRNA in the rat brain. FEBS Lett 438:71-75. CrossRef Medline

Ungless MA, Whistler JL, Malenka RC, Bonci A (2001) Single cocaine exposure in vivo induces long-term potentiation in dopamine neurons. Nature 411:583-587. CrossRef Medline

van den Pol AN, Gao XB, Obrietan K, Kilduff TS, Belousov AB (1998) Presynaptic and postsynaptic actions and modulation of neuroendocrine neurons by a new hypothalamic peptide, hypocretin/orexin. J Neurosci 18:7962-7971. Medline

Vittoz NM, Berridge CW (2006) Hypocretin/orexin selectively increases dopamine efflux within the prefrontal cortex: involvement of the ventral tegmental area. Neuropsychopharmacology 31:384-395. CrossRef Medline

Vittoz NM, Schmeichel B, Berridge CW (2008) Hypocretin/orexin preferentially activates caudomedial ventral tegmental area dopamine neurons. Eur J Neurosci 28:1629-1640. CrossRef Medline

Yeoh JW, James MH, Jobling P, Bains JS, Graham BA, Dayas CV (2012) Cocaine potentiates excitatory drive in the perifornical/lateral hypothalamus. J Physiol 590:3677-3689. CrossRef Medline

Zheng F, Johnson SW (2001) Glycine receptor-mediated inhibition of dopamine and nondopamine neurons of the rat ventral tegmental area in vitro. Brain Res 919:313-317. CrossRef Medline 